\title{
Electrosynthesis of trimethylorthoformate on BDD electrodes
}

\author{
ROMAIN FARDEL ${ }^{1}$, ULRICH GRIESBACH ${ }^{2}, *$ HERMANN PÜTTER $^{2}$ and CHRISTOS COMNINELLIS ${ }^{1, *}$ \\ ${ }^{1}$ Ecole Polytechnique Fédérale de Lausanne (EPFL), Institute of Chemical Sciences and Engineering (ISIC), 1015, \\ Lausanne, Switzerland \\ ${ }^{2}$ BASF Aktiengesellschaft, Forschung und Technologie Chemikalien, GCI/E - M311, 67056, Ludwigshafen, \\ Germany \\ (*author for correspondence, e-mail: christos.comninellis@epfl.ch)
}

Received 30 May 2005; accepted in revised form 1 September 2005

Key words: anodic methoxylation, boron-doped diamond, electroorganic synthesis, methoxy radicals

\begin{abstract}
The anodic methoxylation of formaldehyde dimethylacetal (FADMA) to trimethylorthoformate (TMOF) in basic methanol was investigated on boron-doped diamond (BDD) electrodes. Cyclic voltammetry and preparative electrolysis have shown that FADMA is electrochemically inactive in the solvent stability region; nevertheless FADMA can be oxidized in the potential region of methanol oxidation. A reaction scheme involving intermediates of methanol oxidation (methoxy radicals) has been proposed.
\end{abstract}

\section{Introduction}

The anodic oxidation of organic compounds continues to be an active area of research. Significant progress has been made in recent years, thanks to the availability of new electrode materials like synthetic boron-doped diamond (BDD) thin film based electrodes.

$\mathrm{BDD}$ is a new $\mathrm{sp}^{3}$ carbon based material that has received much attention over the last decade. The BDD electrode has been mainly investigated in aqueous electrolyte and it has been found to behave completely differently from the $\mathrm{sp}^{2}$ graphite electrode. The main characteristics of BDD in aqueous media are: (i) high chemical and electrochemical stability; (ii) high overpotential for oxygen evolution; (iii) formation of very reactive hydroxyl radicals under anodic polarization at high potential [1-7].

BDD anodes have been used for the anodic electroincineration of organic pollutants, wastewater treatment [8-11], preparation of strong oxidants like peroxodisulfuric acid [12, 13] and for electroorganic synthesis in aqueous media [12-15].

Examples of electroorganic synthesis using diamond in non-aqueous media are rare. To the few transformations reported belong the fluorination of 1,4-difluorobenzene in liquid $\mathrm{Et}_{4} \mathrm{NF} \cdot 4 \mathrm{HF}$ [16], the electrochemical cleavage of 1,2-diphenylethanes [17], the methoxylation of $p$-tert-butyltoluene to the corresponding acetal [18] as well as the $\alpha$-methoxylation of DMF [19] and the methoxylation of furan to 2,5-dimethoxy-2,5dihydrofuran [20].
Trimethylorthoformate (TMOF) is an important intermediate for the synthesis of many fine chemicals, it has been also reported that TMOF has a high dehydrating power and can be used as a very effective solvent in order to drive condensation reactions in which water must be eliminated from the reaction media.

TMOF is produced at industrial scale by two major processes. The first proceeds from sodium methanolate and chloroform, but produces three times the stoichiometry of sodium chloride as waste [21]. The second uses cyanhydric acid, which also produces stoichiometric amounts of ammonium salts and, furthermore, involves high safety costs [22].

In this work we propose a new pathway for TMOF production through anodic methoxylation of formaldehyde dimethylacetal (FADMA) in basic methanol, using BDD electrodes:

$$
\widehat{O}_{\mathrm{O}^{-}}^{\stackrel{\mathrm{CH}_{3} \mathrm{OH}}{\longrightarrow}} \underset{-2 \mathrm{e}^{-}-2 \mathrm{H}^{+}}{\stackrel{\mathrm{O}^{\prime}}{\longrightarrow}} \overbrace{\mathrm{O}^{\prime}}
$$

The advantages are attractive raw materials, available from synthesis gas, little waste generated and safer operating conditions.

\section{Experimental}

A one compartment electrolytic cell was used in the setup given in Figure 1. In this setup BDD $(10 \mathrm{~cm}$ 


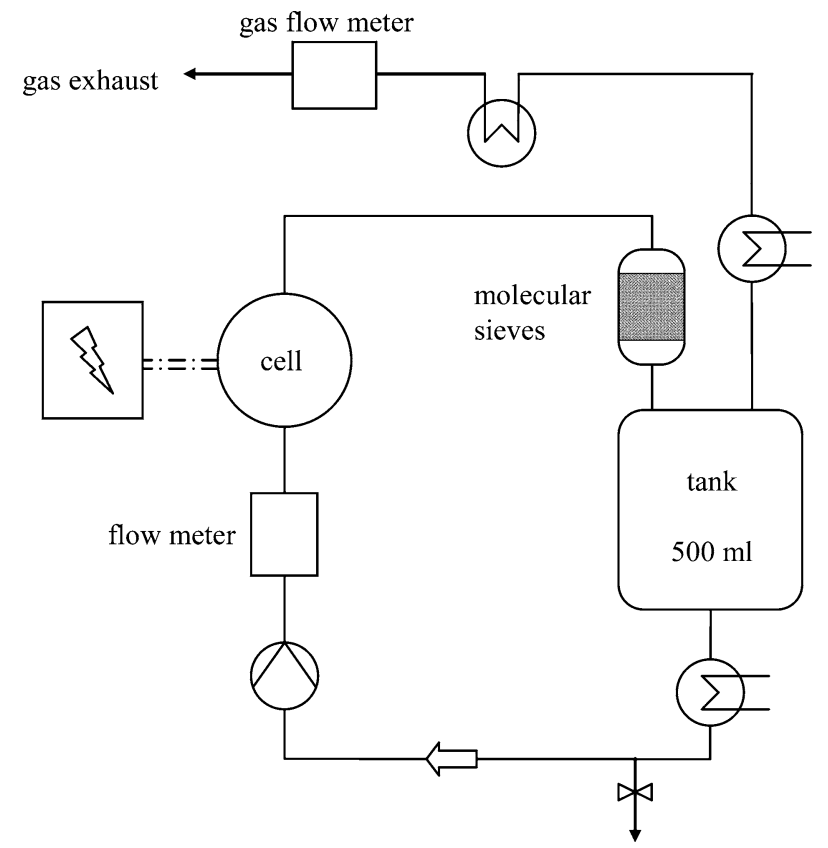

Fig. 1. Experimental set-up.

diameter) supported on silicon (CSEM, Neuchâtel, Switzerland - carrier concentration $1.9 \times 10^{20}$ atoms/ $\mathrm{cm}^{3}$ ) was used as anode and commercial stainless steel (AISI 304) as cathodes (10 cm diameter). The electrodes were arranged vertically (distance anode-cathode: $3.4 \mathrm{~mm}$ ) and the electrolyte was pumped through the circuit using a Teflon coated magnetic pump (Iwaki Magnet Pump MD-30R-220N). The volumetric flow rate $\left(1201 \mathrm{~h}^{-1}\right)$ was controlled using a Krohne Holland Altometer IFS5000/6 (residence time of the electrolyte in the cell: $0.65 \mathrm{~s}$ ). Water was removed using a 3 to $4 \AA$ molecular sieve contained in a vessel inserted in the loop.

The electrolysis solutions used in the experiments were prepared using FADMA (Merck), $\mathrm{MeOH}$ (BASF) and $\mathrm{MeONa}$ (Fluka). The supporting electrolyte was methyltributyl-ammonium methylsulfate (MTBS) from BASF.

The temporal evolution of reactants and reaction products during electrolysis was followed by gas chromatography using an Agilent 6890 Series GC System with a $30 \mathrm{~m}$ DB-1 $5 \mu \mathrm{m}$ column. The following temperature program was used: $50{ }^{\circ} \mathrm{C}$ for $6 \mathrm{~min}$, then $10{ }^{\circ} \mathrm{C} \min ^{-1}$ up to $260{ }^{\circ} \mathrm{C}$. The internal standard adipodinitrile allowed quantification of the products of main interest. The experiments were conducted under galvanostatic conditions.

Cyclic voltammetry was performed using a BDD microelectrode array on Si substrate (106 microelectrodes of $5 \mu \mathrm{m}$ diameter) obtained from CSEM (Neuchâtel, Switzerland). A Pt wire was used as pseudo-reference electrode allowing comparison of two experiments carried out under the same conditions. Potential was reported relative to ferrocenium ion/ ferrocene. The scan rate was $100 \mathrm{mV} \mathrm{s}^{-1}$ and the electrolyte was $\mathrm{MeOH}$ containing $0.14 \mathrm{M}$ MTBS.

\section{Results and discussion}

\subsection{Electrochemical measurements}

Figure 2 shows cyclic voltammograms of the solventsupporting electrolyte (SSE) solution $(\mathrm{MeOH}+0.14 \mathrm{M}$ MTBS) in the absence and presence of different amounts of FADMA using both neutral (SSE + FADMA) and basic media (SSE + 0.016 M MeONa + FADMA). The fact that the presence of FADMA does not influence the cyclovoltammograms of the SSE significantly indicates, that FADMA is electrochemically inactive in the potential region of SSE stability. However oxidation of FADMA in the potential region of SSE decomposition, involving intermediates of solvent oxidation (methanol), could not be excluded; in fact it has been previously reported that in aqueous media oxidation

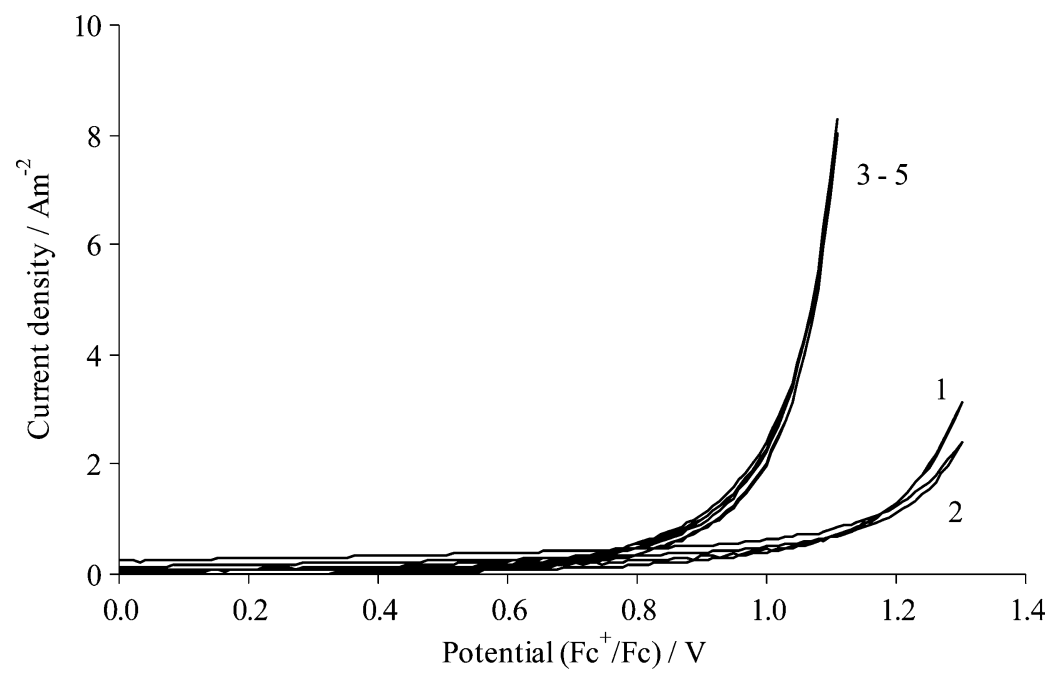

Fig. 2. Cyclic voltammogram of SSE (1), SSE $+1.1 \times 10^{-2}$ м FADMA (2), SSE $+1.6 \times 10^{-2} \mathrm{M}$ MeONa (3), SSE $+0.11 \mathrm{M}$ FADMA + $1.6 \times 10^{-2}$ м MeONa (4), SSE +0.55 м FADMA + $1.6 \times 10^{-2}$ м MeONa (5). SSE: $\mathrm{MeOH}+0.14$ м MTBS, scan rate: $100 \mathrm{mV} \mathrm{s}^{-1}$, room temperature. 

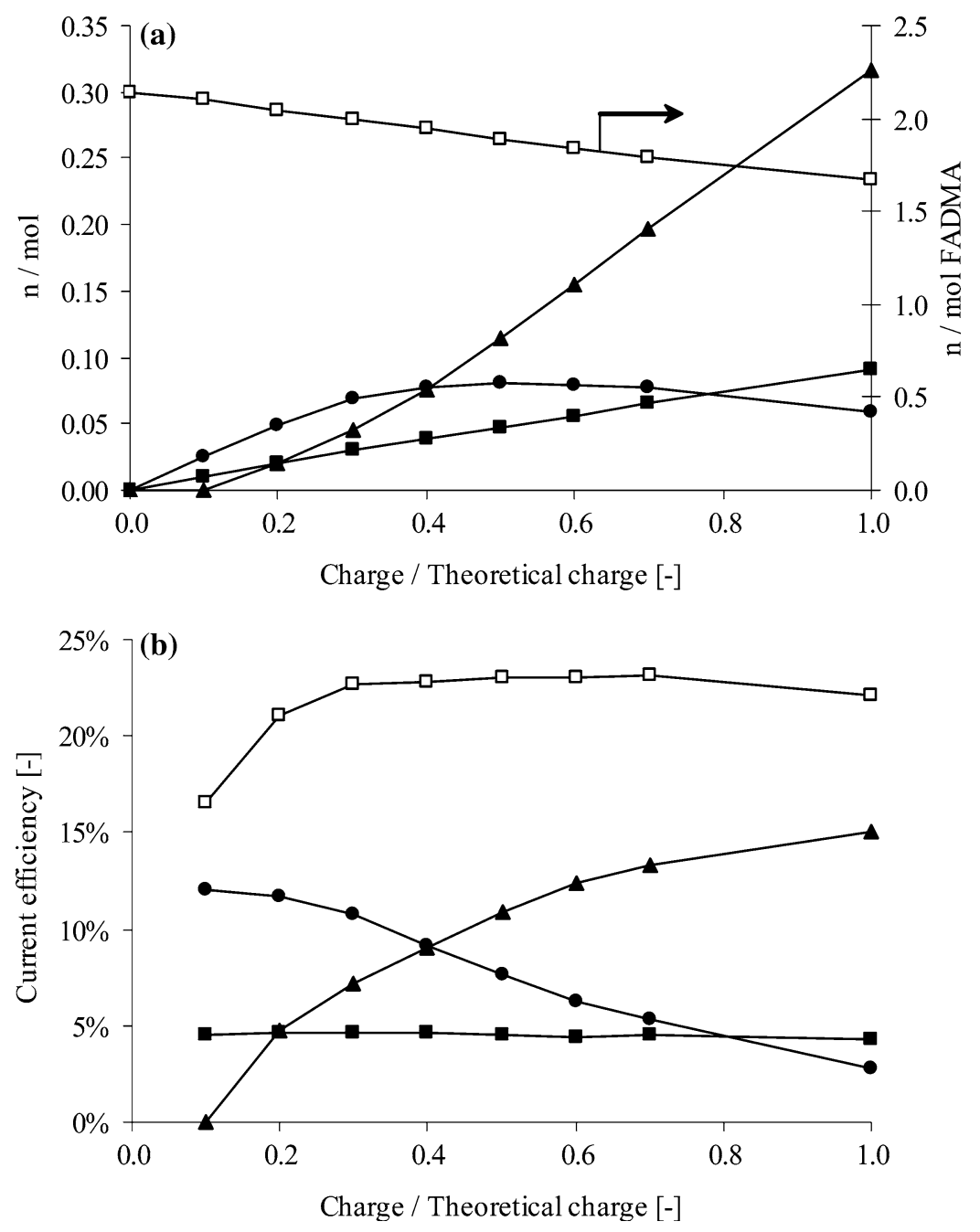

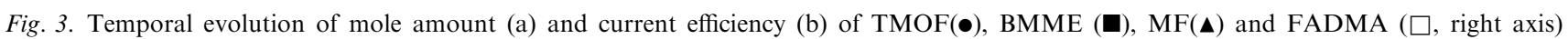
during the electrolysis of FADMA $(4.6 \mathrm{M})$ in $500 \mathrm{ml}$ of supporting electrolyte $(\mathrm{MeOH}+0.16 \mathrm{M} \mathrm{MeONa}+0.14 \mathrm{~m}$ MTBS). Current density $=18 \mathrm{~A} \mathrm{dm}^{-2}, T=40^{\circ} \mathrm{C}$.

of organics on BDD anodes takes place in the potential region of water decomposition involving hydroxyl radicals $[3,5,10-12]$.

The decrease in the onset potential of the SSE decomposition in basic media is certainly related to favorable thermodynamic conditions of methanol oxidation in basic media. In fact the electrochemical oxidation of methanol in basic media $(\mathrm{MeOH}+$ $\mathrm{MeONa}$ ) leads to the formation of formaldehyde [23-27].

$$
\mathrm{CH}_{3} \mathrm{OH} \rightarrow \mathrm{HCHO}+2 \mathrm{H}^{+}+2 \mathrm{e}^{-}
$$

From this reaction (Equation 2) we can expect a shift in the thermodynamic potential of methanol oxidation to less positive values with increasing $\mathrm{pH}$.

\subsection{Preparative electrolysis}

Figure 3a shows that during electrolysis of formaldehyde dimethylacetal (4.6 M FADMA) in the solventsupporting electrolyte solution $(\mathrm{MeOH}+0.16 \mathrm{M}$ $\mathrm{MeONa}+0.14 \mathrm{M}$ MTBS), the desired product TMOF firstly increases with the electrical charge then passes through a maximum before starting to decrease. Concerning the two main by-products methyl formate (MF) and bis-methoxymethylether (BMME), both increase continuously with the electrical charge passed.

Figure $3 \mathrm{~b}$ shows, that the current efficiency for TMOF formation decreases and that of MF formation increases with electrical charge passed; however, the current efficiency of BMME formation remains almost constant.

Figure $3 \mathrm{a}$ and $\mathrm{b}$ also show that both FADMA conversion and the sum of the current efficiency for the three products TMOF, MF and BMME after the passage of the theoretical electrical charge do not exceed $25 \%$. This indicates, as expected from cyclovoltammetric measurements, that FADMA oxidation on BDD takes place with simultaneous oxidation of methanol.

Considering these results a reaction scheme can be proposed (Figure 4). The first step is the anodic discharge of methanolate leading to the formation of methoxy radicals (Equation I, Figure 4). These radicals can be either further oxidized to formaldehyde 


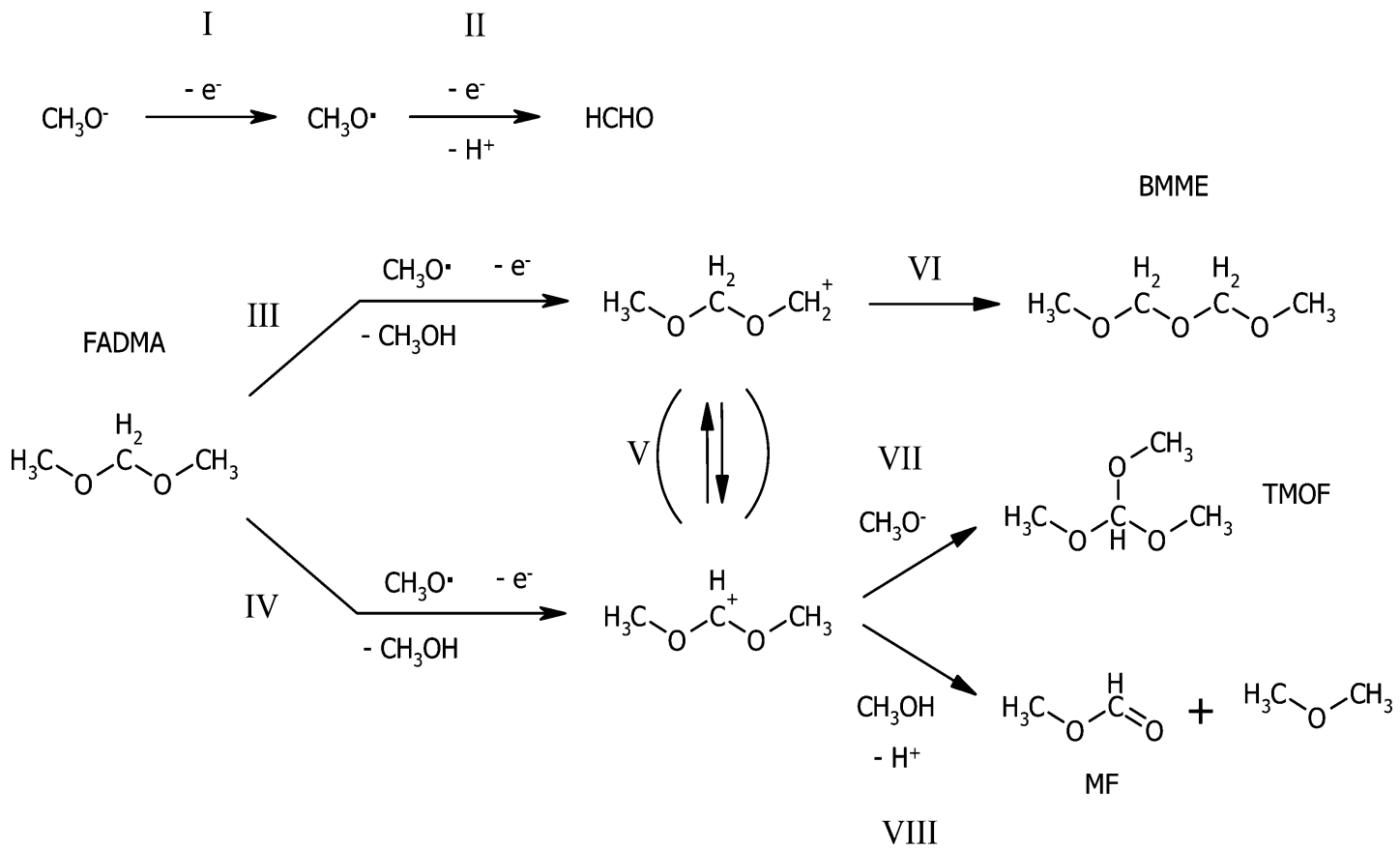

Fig. 4. Mechanism of the overall reaction of FADMA.

(Equation II, Figure 4) or react with FADMA giving two possible carbocations (Equations III and IV, Figure 4). Despite the statistical and sterical advantage of the terminal carbon cation, the central one is preferentially formed due to its more favorable charge delocalization.

Both central and terminal carbocations react with methanolate giving BMME and TMOF respectively (Equations VI and VII, Figure 4.). The formation of MF during electrolysis indicates a possible side reaction for the central carbocation intermediate, by reaction with methanol, leading to the cleavage product (Equation VIII, Figure 4).

In fact it has been reported [28, 29] that for this type of carbocation there is a concurrence between two reaction pathways: reaction with hard nucleophile $\left(\mathrm{MeO}^{-}\right)$leading to the addition product (TMOF) or reaction with a soft nucleophile $(\mathrm{MeOH})$ leading to the formation of MF.

\section{Acknowledgements}

Financial support from the Fonds National Suisse de la Recherche Scientifique and the BASF Aktiengesellschaft is gratefully acknowledged.

\section{References}

1. R. DeClements and G.M. Swain, J. Electrochem. Soc. 144 (1997) 856.

2. T.N. Rao and A. Fujishima, Diam. Relat. Mater. 9 (2000) 384.

3. I. Duo, P.A. Michaud, W. Haenni, A. Perret and C. Comninellis, Electrochem. Solid-State Lett. 3 (2000) 325.
4. M.C. Granger, M. Witek, J. Xy, J. Wang, M. Hupert, A. Hanks, M.D. Koppang, J.E. Butler, G. Lucazeau, M. Mermoux, J.W. Strojek and G.M. Swain, Anal. Chem. 72 (2000) 3793.

5. G. Fóti, D. Gandini, C. Comninellis, A. Perret and W. Haenni, Electrochem. Solid-State Lett. 2 (1999) 228.

6. S. Alehashem, F. Chambers, J.W. Strojek, G.M. Swain and R. Ramesham, Anal. Chem. 67 (1995) 2812

7. G.M. Swain, J. Electrochem. Soc. 141 (1994) 3382

8. A. Morao, A. Lopez, M.T. Pessoa de Amorim and I.C. Goncalves, Electrochim. Acta 14 (2004) 1587.

9. C. Levy-Clement, N.A. Ndao, A. Katty, M. Bernard, A. Deneuveville, C. Comninellis and A. Fujishima, Diam. Relat. Mater. 12 (2003) 606.

10. F. Montilla, P.A. Michaud, E. Morallon, J.L. Vazquez and C. Comninellis, Electrochim. Acta 47 (2002) 3509.

11. M. Panizza, P.A. Michaud, G. Cerisola and C. Comninellis, Electrochem. Commun. 3 (2001) 336.

12. P.A. Michaud, E. Mahé, W. Haenni, A. Perret and C. Comninellis, Electrochem. Solid-State Lett. 3 (2000) 77.

13. H.-J. Förster, W. Thiele, D. Fassler and K. Günther, New Diam. Front. Carbon Technol. 12 (2002) 99.

14. N. Katsuki, E. Takahashi, M. Toyoda, T. Kurosu, M. Iida, S. Wakita, Y. Nishiki and T. Shimamane, J. Electrochem. Soc. 145 (1998) 2358.

15. S. Ferro, A. DeBattisti, I. Duo, C. Comninellis, W. Haenni and A. Perret, J. Electrochem. Soc. 147 (2000) 2614

16. F. Okino, H. Shibata, S. Kawasaki, H. Touhara, M. Kunitake, M. Nishitani-Gamo, I. Skaguchi and T. Ando, Electrochem. SolidState Lett. 2 (1999) 382.

17. D. Zollinger, U. Griesbach, H. Pütter and C. Comninellis, Electrochem. Commun. 6 (2004) 605.

18. D. Zollinger, U. Griesbach, H. Pütter and C. Comninellis, Electrochem. Commun. 6 (2004) 600.

19. BASF AG, EP $1036861 \mathrm{~B} 1,(2000)$.

20. Degussa AG, DE 10313169 A1, (2004).

21. Hüls Chemische Werke AG, DE 3606472 A1, (1987).

22. J.G. Erickson, J. Org. Chem. 20 (1955) 1573.

23. T. Inoue, K. Koyama and S. Tsutsumi, Bull. Chem. Soc. Japan 37 (1964) 1597.

24. G. Sundholm, J. Electroanal. Chem. 31 (1971) 265

25. C. Iwakura, T. Hayashi, S. Kikkawa and H. Tamura, Electrochimica Acta 17 (1972) 1085. 
26. G.-A. Mazzocchin, G. Bontempelli and F. Magno, J. Electroanal. 28. U. Pindur, J. Müller, C. Flo and H. Winzel, Chem. Soc. Rev. 16 Chem. 42 (1973) 243. (1987) 75.

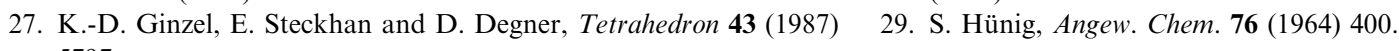
5797. 